\title{
Analysis of Youth Participation in Hides and Skin Processing and Marketing in Sokoto-Metropolis, Sokoto State, Nigeria
}

\author{
Aliyu M. S ${ }^{1}$, Harande Y. A ${ }^{2}$, Umar M $^{3}$, Sani Khalid Mohammed ${ }^{4}$, and Eze Abdullahi D. $\mathbf{U}^{5}$ \\ ${ }^{1 *}$ Researcher, Directorate of Research and Development, Nigerian Institute of Leather and Science \\ Technology, Zaria, Kaduna, Nigeria \\ ${ }^{2}$ Researcher, Department of Administrative and Leadership Education. Indiana University of \\ Pennsylvania. USA. \\ ${ }^{3}$ Lecturer, Department of Science Laboratory Technology, Nigerian Institute of Leather and Science \\ Technology, Zaria, Kaduna, Nigeria. \\ ${ }^{4}$ Lecturer, Department of General Studies, Nigerian Institute of Leather and Science Technology, \\ Samaru-Zaria, Kaduna state, Nigeria. \\ ${ }^{5}$ Lecturer, Department of Business Education, Federal College of Education, Zaria, Kaduna state,
} Nigeria

\begin{abstract}
Livestock breeding with other related activities the most important sectors of agriculture provide the population with food and essential raw materials. The aim of this study is to describe the socio-economic characteristics of the youth participating in hide and skin processing and marketing in the study area, and to describe the level of youth participation in hide and skin processing and marketing; with view to determine the cost and return in hide and skin processing and marketing; as well as to evaluate the constraint encountered by youth involved in hide and skin processing and marketing in the study area. A total number of 100 samples were collected with the aid of a structured questionnaire. The information was collected based on socio-demography, hide and skin processing methods practiced by respondents, and constraints faced by the processor in the study area. Descriptive statistics were used to analyze the data collected, which involves the use of measures of central tendency such as means, frequency distributions and percentages to describe the socio-economic characteristics of leather processors in the study area and the constraint confronting the leather processing and marketers. It was found that quality control assessment of the product, poor extension services, lack of protective wears, expose to dangerous chemicals were seen to have a significant effect on the participation of youth in hide and skin processing and marketing. Age, marital status, household size, and training experience had no effect on the youth's participation in the hide and skin processing and marketing. The study also found that despite the constraint youth experienced in the study area, they still contributed greatly to tanning activities and were willing to continue with tanning activities as a profession.
\end{abstract}

Key words: Hides and Skin, Youth, Processing, Marketing, Tanning, Income, Sokoto.

\section{INTRODUCTION}

Hides and skins are the main export income generators from the livestock sector in Africa. In the year 2000, Africa's share of total world production was only $5 \%$ of bovine hides, $14 \%$ of goat and kidskins and $8 \%$ of sheep and lambskins (UNDP, 2005). The potential of Nigeria in the production of hides and skins may be assessed from the slaughter statistics. On the average, Nigeria 
produces over one million hides and about three million skins per year from the registered abattoirs and slaughterhouses. Many animals are slaughtered outside these registered premises and the utilization of the resultant hides and skins is unaccounted for. Hides and skins are an end product of animal production. As an end product - although more correctly they are a by-product they are an important and valuable resource. In the developing world they are almost never exploited to anything like their full potential. Hides and skins are a renewable resource of national and international significance. They provide scope for exploitation on a sustainable long-term basis. More particularly, production and marketing of hides and skins provide opportunities to support and sustain livelihoods especially in rural areas. In order to operate successful ventures, however, there must be a suitable business structure and the hides and skins must be treated as commercial assets (Ihuoma et al., 2001).

Tanning of hides and skins into leather is one of the main industrial activities of the North West, particularly in Kano and Sokoto States, Nigeria. According to Nigerian Tanners Council (2009), over 85\% of the tanneries in Nigeria are found in these states. The value chain actors in hides and skins processing include the butchers, tanners, hides and skins wholesalers (dealers) and leather wholesalers. As processing and marketing of hides and skins is very important to the industrial activities of the region, effort is required to investigate the level of participation in local leather industry to hides and skins processing into leather and their marketing in Sokoto State.

Youth has been defined as individuals male or female, above the age of ten but below thirty years of age (Alao, 1978; Olujide, 2008). The youth has also been viewed as a concept, defined as the period in an individual's life which runs between the end of childhood and entry into the world of work (Onuekwusi and Effiong, 2002). Youths are one of the greatest assets that any nation can have (Federal Republic of Nigeria, 1999). Not only are they legitimately regarded as the future leaders, they are, potentially and actually the greatest investment for a country's development (Federal Republic of Nigeria, 1999; Olujide, 2008). According to Nigeria's National Youth Development Policy (2001), the youth comprises all young persons of ages 18 to 35, who are citizens of the Federal Republic of Nigeria. This category represents the most active, the most volatile and yet the most vulnerable segment of the population. The global population of young people aged 12-24 is currently 1.3 billion. The youth population is projected to peak at 1.5 billion in 2035 and it will increase most rapidly in Sub-Saharan Africa (SSA) and South East Asia (by 26 percent and 20 percent respectively between 2005 and 2035) (FAO, 2004).

Youth is the time of life when one is young, but often means the time between childhood and adulthood (maturity) (UNESCO, 2005). Youths constitute a formidable force for sustainable agricultural development of any nation particularly the agrarian ones including Nigeria (Ogunremi, 2012). This is because youths possess a lot of energies and other inestimable assets for productivity and general sustainable socio-economic development (Iwala 2006; Ogunremi, 2012). A major concern of the Federal Government in Nigeria is how to tackle the problem of unemployment among the youths in the country. Many Nigerian states have designed and execute several self-empowerment programmes to enhance the economic empowerment of their youths (Umeh and Odo 2002; Ogunremi, 2012). Youths are rightly seen as leaders of tomorrow. Hence, the kind of education (formal or informal) that youth are exposed to or have access to will determine the nation's overall development. It has been observed that if we meet up with the challenge of the rural sector, the youth that constitute part of the population that makes up the rural areas, have certain roles to play in the process of rural development. These include social, economic, political and civil roles, which will aid the development of rural areas and the nation in general. However, these young people do not know how they can contribute their best to the development of their areas.

Hides and skins are a renewable resource of national and international significance. They provide scope for exploitation on a sustainable long-term basis. More particularly, production and marketing of hides and skins provide opportunities to support and sustain livelihoods especially in rural areas. In order to operate successful ventures, however, there must be a suitable business structure and the hides and skins must be treated as commercial assets. The Sokoto Central Abattoir, designed as a full-fledged mechanized plant, was established in 1966 with a rated capacity to slaughter up to 150 head of cattle and 500 small ruminants per day (UNIDO, 2005). At present the daily kill is about 40-60 heads of cattle and some 200 sheep and goats. The actual slaughter operation takes place on the floor by employing some rudimentary methods, also the flaying of hides is carried out on the floor, making it very difficult to avoid flay cuts and holes. It seems the damages afflicted to the hide is of minor concern to the hide owner as nearly $80 \%$ or more of the hides produced are taken up by the "pomo market" a ready uncomplicated outlet for fresh hides at attractive returns (Naira 700-1500/hide - the number of holes and cuts is of no concern as the hide will be cut into strips anyway) (UNIDO, 2005).

The research study targeted to describe the socio-economic characteristics of the youth participating in hide and skin processing and marketing in the study area; and to describe the level of youth participation in hide and skin processing and marketing; with view to determine the cost and return in hide and skin processing and marketing; as well as to evaluate the constraint encountered by youth involved in hide and skin processing and marketing in the study area. 


\section{MATERIALS AND METHODS}

\subsection{The Study Area}

The study was carried out in Sokoto State. The State is located in the extreme North-western part of Nigeria. It is located between latitudes $4^{\circ}-6^{\circ} 40 \mathrm{~N}$ and longitudes $11^{\circ} 30-15^{\circ} 50 \mathrm{E}$. The state has an estimated population of 3, 696, 999 (NPC, 2006). The projected population of $4,761,734$ people in 2015 at a growth rate of 3.2 percent per annum makes the state populous. There are two distinct seasons in the state; the rainy season which starts around May and lasts till September, and the dry season from October to April. The annual rainfall is frequently erratic, poorly distributed and varies from $500 \mathrm{~mm}$ to $1300 \mathrm{~mm}$. There are two temperature extremes; the hot period (March to May) which is as high as $39^{\circ} \mathrm{C}$ and the cold harmattan months of December to January, when cold, dust-laden winds blow from across Sahara bringing down the temperature to as low as $15^{\circ} \mathrm{C}$ averaging about $27^{\circ} \mathrm{C}$ (SMANR, 1998). The climate of the state is largely controlled by two recasting air masses. The moist tropical maritime from the south which blows from the Atlantic Ocean and the tropical continental wind from the north across the Sahara which is dry and dusty that brings the harmattan (SMANR, 2007). The rainy season is from June to October, The mean annual rainfall is $750 \mathrm{~mm}$ and potential evapotranspiration rate has been reported to be $102 \mathrm{~cm}$.

The major occupation is farming followed by trading and local rearing of animals. Livestock include cattle, sheep, goats and poultry which provide food for human consumption with potentials of providing raw materials for industries. Sokoto is predominantly a Muslim community. Fulani and Hausa are the main ethnic groups in the state. However, there is considerable number of Fulani cattle herders, whose males rear livestock, while the females hawk locally prepared fermented milk in towns and villages and majority of the youth involves in working at local tanneries.

\subsection{Sampling Technique and Sample Size}

Two-stage sampling procedure was employed for the study. The first stage, two communities was purposively selected in two Sokoto based on the intensity in leather production namely: Majemar Karaye and Majemar Unguwan Rogo. Secondly thirty percent (30\%) of leather producers and $30 \%$ of marketers in each community were selected using simple random techniques. A total of one hundred respondents were selected for the study as indicated in Table 1.

Table 1: population and sample size of youth involved in leather processing

\begin{tabular}{lllllll}
\hline SELECTED COMMUNITY & $\begin{array}{l}\text { Processor } \\
\text { Sample Frame }\end{array}$ & $\begin{array}{l}\text { Sample } \\
(30 \%)\end{array}$ & $\begin{array}{l}\text { Size } \\
\text { Frame }\end{array}$ & $\begin{array}{l}\text { Sample } \\
\text { Sample } \\
(30 \%)\end{array}$ & Size \\
\hline Majemar Karaye & 102 & 31 & 54 & 16 \\
Majemar Unguwan Rogo & 121 & 36 & 60 & 34 \\
Total & 223 & 67 & 114 & \\
\hline
\end{tabular}

Source: reconnaissance survey,

\subsection{Method of Data Collection}

Primary data were used for this study. Having collected with the aid of structured questionnaire, the information were collected on (a) respondents socio-economic characteristics such as age, household size, educational status, marital status and gender of household youth head. (b) Processing method practiced by respondents (c) Constraints faced by the processor in study area.

\section{Analytical Techniques}

The tools used in the analysis include, descriptive statistics and gross margin analysis

\subsubsection{Descriptive statistics.}

Descriptive statistics was used to achieve the study objectives. It involved the use of measures of central tendency such as means, frequency distributions and percentages to describe the socio-economic characteristics of leather processors in the study area and the constraint confronting the leather processing and marketers. 


\section{Gross Margin Analysis}

The Gross margin (GM) was adopted from the work of Olukosi and Erhabor (1988). It was used to estimate the costs and returns of leather production. The formula for the gross margin model is stated as follows:

$\mathrm{GM}=\mathrm{GI}-\mathrm{TVC}$ $-\mathbf{- I}$

Where,

$\mathrm{GI}=$ Gross income $(\mathrm{A})$;

$\mathrm{TVR}=$ total variable revenue $(\mathbb{A})$;

TVC $=$ total variable cost $(\mathbb{N})$ and

The gross income was obtained by multiplying, while the total variable cost comprised of costs of input and output

Returns per naira invested (RNI) was obtained by dividing the gross income (GI) by the total cost (TVC).

Therefore,

$\mathrm{RNI}=(\mathrm{GI}) \mathrm{TVC}$ II

$$
\underset{\mathrm{i}}{\mathrm{RNI}}=\frac{(\mathrm{GI})}{\mathrm{TVC}}
$$

Where,

$\mathrm{RNI}=$ returns per Naira invested

$\mathrm{GI}=$ gross income and

$\mathrm{TVC}=$ total variable cost

Decision Rule:

RNI $>>1$, it implies the enterprise is profitable;

$\mathrm{RNI}=1$, it implies that the leather tanners is operating at breakeven point and

$\mathrm{RNI}<1$, the leather tanners is at loss

\section{RESULTS AND DISCUSSIONS}

\subsection{Socio-economic characteristics of the respondents}

\subsubsection{Age of the respondents}

One of the socio-economic characteristics this study investigated is age. In the study, results from Table 1 shows that the majority of the youths interviewed (66\%) were between 30 and 49 years, 19\% were between 20-29 years. While during the survey, some respondents stated that they started the business of hide and skin processing and marketing as early as age 7years (Table 2). This coincides with the findings of Daniel et al (2017), who reported highest percentage of tanning participation among respondents of 
age range between 30 years and above. This may probably be as a result of engagement into productive stage by middle-aged individuals at Northern Nigeria, where youths participate in tanning to get income for the sustainability of their livelihoods.

Table 2 Age of Respondents

\begin{tabular}{lll}
\hline Age & Frequency & Percentage \\
\hline $20-29$ & 19 & 19 \\
$30-39$ & 47 & 47 \\
$40-49$ & 23 & 23 \\
\hline Total & 100 & 100 \\
\hline
\end{tabular}

\subsubsection{Marital status}

The result in Table 3 shows that $78 \%$ of the respondents were married and they engage in hide and skin processing and marketing so as to make optimum profit to support their families, $22 \%$ of the respondents were single. This shows that positive relationship between married and single respondents in the marketing of hide and skin processing (Table 3). This finding is close to the findings of Anil and Suraiya (2014), who reported that predominant (65.9\%) people who engage in hide and skin processing are married, while the remaining $34.1 \%$ are not married. This may be due to the struggle by the married couples in order to cater for their home needs.

Table 3. Marital Status

\begin{tabular}{lll}
\hline & Frequency & Percentage \\
\hline Single & 22 & 22 \\
Married & 78 & 78 \\
\hline Total & 100 & 100 \\
\hline
\end{tabular}

\subsubsection{Educational Level}

The importance of education cannot be overemphasized. Education is an effective tool in running a business. An educated business businessman has little or no difficulty in recording his business activities. The result of the data from the entire respondents shows that $83 \%$ had formal education and $17 \%$ has no formal education. This shows that out of all the hide and skin processors and marketers, $20 \%$ had primary education, $43 \%$ had secondary education, $20 \%$ had tertiary education while $7 \%$ had adult education (Table 4). This concurs with the study of Anil and Suraiya (2014), whor documented highest percentage (53.3\%) of tannery workers with secondary school certificates, with least percentage of the tannery workers who graduated from higher institution. This may probably be as a result of high expectations of white collar jobs by the graduates at Northern Nigeria, that sometimes belittle most businesses that are not formal, as most graduates prefer to be in civil service.

Table 4. Educational Level

\begin{tabular}{lll}
\hline & Frequency & Percentage $(\%)$ \\
\hline Non formal & 10 & 10 \\
Primary & 20 & 20 \\
Secondary & 43 & 43 \\
Tertiary & 20 & 20 \\
Adult education & 7 & 7 \\
\hline Total & 100 & 100 \\
\hline
\end{tabular}

\subsubsection{Tanning Experience}

The result shows that $48 \%$ of the respondents have 10-20 years tanning experience while $5 \%$ of the respondents have 30 and above years tanning experience. Others are 32\% have 1-10 years experience and 15\% have 20-30 tanning experience of hide and skin processing and marketing (Table 5). This is not in agreement with the findings of Anil and Suraiya (2014) conducted at Dhaka, Bangladesh, who reported highest percentage of tannery working experience among tanners that have 2-6 years of experience. Almost about $75 \%$ of the workers have been working in the tannery for not more than 11 years in their study. This may be due to the idea of getting into hide and skin processing to sustain one's life, after which the tanners look for other alternative sources of income at Bangladesh, but in Nigeria, some tanners take the tanning business as a profession, as such 
individual tanners tend to stay in the business for a long period of time in order to build up a career in it despite the challenges associated with the business.

Table 5. Tanning Experience

\begin{tabular}{lll}
\hline Year & Frequency & Percentage (\%) \\
\hline $1-10$ & 32 & 32 \\
$10-20$ & 48 & 48 \\
$20-30$ & 15 & 15 \\
30 and above & 5 & 5 \\
\hline Total & 100 & 100 \\
\hline
\end{tabular}

\subsection{Level of Youth Participation in Hide and Skin Processing and Marketing}

\subsubsection{Types of Tanning Methods in which Respondents are Involved}

The result showed that majority of the respondents engage in vegetable tanning which represented $95 \%$, while minerals, aldehyde and oil representing 3\%,2\% and 1\% (Table 6). This may be due to the low cost of tannery effluent treatment when tanners use vegetable method for tanning process, as most countries impose a critical sanction to the industries that discharge their effluent without proper treatment as recommended by Umar et al. (2017).

Table 6. Frequency of Tanning Methods involved by the Respondents

\begin{tabular}{lll}
\hline Training & Frequency & Percentage (\%) \\
\hline Vegetable & 95 & 95 \\
Minerals & 73 & 3 \\
Aldehyde & 2 & 2 \\
Oil & 1 & 1 \\
\hline Total & 100 & 100 \\
\hline
\end{tabular}

\subsubsection{Sources of Tanning Labour}

The respondents based on hide and skin processing and marketing were represented in table 7 . The result shows that majority of the respondents; 32\%, 48\%, 12\% and 7\% with respect to hired, family, communal and others respectively (Table 7). This coincides with the findings of Anil and Suraiya (2014), who reported majority of the tanning business as family business and some hired workers with long period of experience.

Table 7. Sources of Tanning Labour

\begin{tabular}{lll}
\hline & Frequency & Percentage (\%) \\
\hline Hired & 32 & 32 \\
Family & 49 & 49 \\
Communal & 12 & 12 \\
Others & 7 & 7 \\
\hline Total & 100 & 100 \\
\hline
\end{tabular}

\subsubsection{Leather processing}

The study shows that majority of the respondents (18\%) were engaged in tanning and soaking followed by (15\%) marketing. Bating is the least in the process representing 6\% than dying (9\%) (Table 8). Umar et al. (2015) indicated that varied purchase costs but having the same selling value of the finished leather depending on the cost of the processes involved. The modern

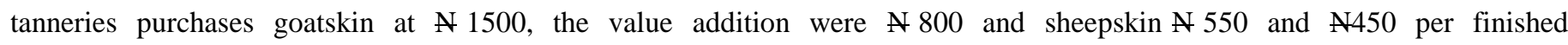
leather respectively. This is as a result of soaking the hides to reduce the cost of processing, as such majority of tanners adopt soaking of hides during processing. 
Table 8. Leather processing

\begin{tabular}{lll}
\hline Activities & Frequency & Percentage $(\%)$ \\
\hline Soaking & 18 & 12 \\
Unhairing & 12 & 12 \\
Deliming & 10 & 10 \\
Pickling & 12 & 12 \\
Training & 18 & 18 \\
Bating & 6 & 6 \\
Dying & 9 & 9 \\
Marketing & 15 & 15 \\
\hline
\end{tabular}

\subsection{Determining the Cost and Return in Hide and Skin Processing and Marketing}

\subsubsection{Distribution of Respondents according to Level of Monthly income}

Out of the total number of tanners assessed in relation to level of income, it was discovered that the level of income fall into the categories with high frequency (36-39\%) of tanners who earn $\$ 151,000$ to above $\$ 201,000$ (USD 1= $\$ 460$ ) (Table 9). This is comparable to the study conducted at Pakistan, where the researchers reported that majority of the workers $(48.7 \%)$ had monthly income of 3000-5000 rupees (1 USD = 60.25 Pak rupees) (Shahzad et al., 2006). It showed that Nigeria paid high salaries among the tannery workers than that of Pakistan.

Table 9. Distribution of Respondents according to Level of Monthly income

\begin{tabular}{lll}
\hline Income & Frequency & Percentage $(\%)$ \\
\hline $50,000-100,000$ & 12 & 12 \\
$101,000-150,000$ & 13 & 13 \\
$151,000-200,000$ & 36 & 36 \\
201,000 and above & 39 & 39 \\
\hline
\end{tabular}

\subsubsection{Cost in Hide and Skin Processing and Marketing}

The scale of skin was measured to be 7 square feet. A square feet was said to cost $\$ 1140$. Cost of raw skin was realized to $¥ 800$ in processing. The total labour cost per square feet consist of family, hired communal was said to $\$ 28$. The total cost of chemical used in processing per square feet was said $\$ 42.85$. Therefore, the total cost of 7 square feet of raw skin was realized to be $\$ 800$, the total cost of labour was realize to $\$ 200.2$ while that of chemicals was $\$ 300$.The total cost of processing 7 square feet of raw skin to leather was $\$ 1300$. This is in contrast to the findings of Umar et al. (2015) who documented that the business is profitable, with the net profit per week (TR -TC) found to be $\$ 34,524.7$ while gross margin was $\$ 52,050$ per week. The value of fixed costs components constituted only $23.2 \%$ of the total cost of production, indicating small scale operation of the business.

\subsubsection{Return on Skin processing}

The cost of sale per square feet was $¥ 300$. The total cost of 7 square feet of processed skin was $¥ 2100$. The estimated value of total return was $\$ 2100$; Gross margin of processed skin was $\$ 800$. This indicates that processed skin is profitable in the study area. A return per square feet of skin invested is $\$ 114.28$, this implies that for every $\$ 100$ invested in skin processing in the study area, there will be a gain of $\$ 14.28$ kobo this shows that skin processing is profitable (Table 10). This deviates from the study of Ismail (2005), who reported that the cost of skin constituted $63 \%$ in leather tanning and finishing stages, value added were $26.1 \%$ and $38.7 \%$ respectively. The value of skin transformed into finished leather increases to $113 \%$ this value increases from 22 million Naira for salted goatskin to 34.6 million Naira tanned leather to 46.8 million naira finished leather. 
International Journal of Research in Social Science and Humanities (IJRSS), Vol. 2, No. 3, May - 2021

Table 10. Cost and Return of Processing Hide and Skin

\begin{tabular}{llll}
\hline & Average quantity per sq feet & Unit price & Value $(\mathbb{N})$ \\
\hline A Raw skin & 114.29 & 7 & 800 \\
Labour & 28.57 & 7 & 200 \\
Chemical & 42.85 & 7 & 300 \\
Total cost & & & 1300 \\
B Return & 300 & 7 & 2100 \\
C Gross margin & & & 800 \\
Return per Naira invested & & & 0.62 \\
\hline
\end{tabular}

\subsection{Constraint Encountered by Youth Involved in Hide and Skin Processing and Marketing in the Study Area}

\subsubsection{Respondents constraints to hide and skin processing and marketing.}

The result indicated that the majority (56\% and above) of the respondents agreed that all marketing with the exception of limited demand of market for hide and skin with 21 respondent representing $21 \%$. Notable among the constraints were inadequate transportation, poor extension services and lack of protective wear e.g. hand glove, rain boot, laboratory coat, no quality control of product which represented $89 \%, 88 \%$ and $84 \%$ respectively (Figure 1). The work of Umar et al (2015) supported this present findings, by pointing out the major problems faced by tanners include poor protective gears, inadequate quality assurance and poor road networks for prompt transportation of processed hides.

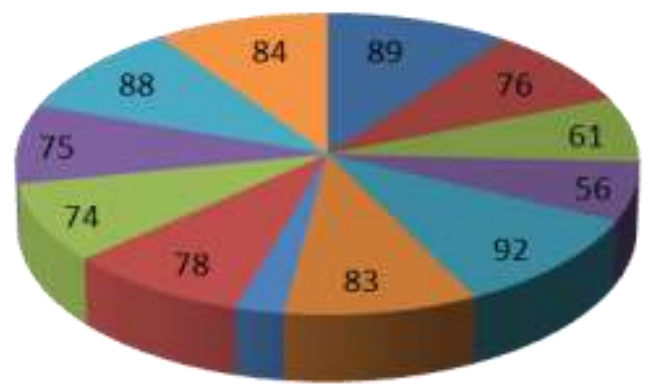

21

\author{
Poor space facilities \\ Inadequate transportation \\ Seasonal fluctuation and \\ price \\ Problems of marketing \\ fees and taxes \\ E Insufficient working capital \\ Inadequate access to \\ credit \\ Limited demand \\ High cost of input \\ Long distance to the \\ market \\ - Poor quality control \\ laboratory \\ - Poor extension services
}

- Lack of protective wear

Fig. 1. Constraints faced by youth in level of hide and skin processing marketing

\section{CONCLUSION}

This study has attempted to capture the relationship between socioeconomic characteristics of youths and participating in hide and skin processing and marketing based on their income. From the study, Quality control assessment of product, poor extension services, lack of protective wears, expose to dangerous chemical were seen to have significant effect on the participation of youth 
in hide and skin processing and marketing. Age, marital status, household size and training experience had no effect on the youths participation in the hide and skin processing and marketing. The study also found that despite the constraint youth experienced in the study area, they still contributed greatly to tanning activities and were willing to continue with tanning activities as a profession.

\subsection{Recommendation}

1. Youth should be encouraged to form and to be part of the youth cooperative society in the Sokoto metropolis area; this will help in alleviating any of the problems faced by the youths in relation to financial commitment.

2. Tanning inputs such as hide and skin improved chemicals should be available at the right time and at subsidized rate. Government at various level should make more effort in monitoring the activities of their officials in order to make sure that all the necessary tanning input/ aids get to the beneficiaries.

3. Government/NGOs should provide adequate credit facilities to the youths, low capital bases in order to encourage their involvement in tanning activities.

4. The Nigerian institute of Leather and Science Technology (NILEST) should be the supervisory of institution that will shoulder the responsibility to check the activities of tanners and tanneries.

5. State and Local Governments should involve in infrastructural development, construction of tannery sites, construction of effluent treatment plants, and provision of water supply and enhance the social life of youth and encourage them in the tanning activities.

6. Adequate market outlets for leather commodity should be established in Sokoto metropolis area to enable tanner to get a good price for their commodity.

\section{REFERENCES}

Anil, G. and Suraiya, N. (2014). Socio-Economic Conditions and Life Style Related Characteristics of Tannery Workers of Hazaribagh, Dhaka: A Cross-Sectional Study. Int. J. Bus. Soc. Sci. Res. 1(3): 176-179. Retrieve from http://www.ijbssr.com/currentissueview/14013031

Alao, J.A. (1976). "Rural Family Under Stress; The changing role of Youth in Nigerias Rural Communities, Implication for Planning and development." Paper presented at the seminar/Workshop on Nigeria Youths, University of Ibadan, Pp. 14.

Daniel, C.L., Fernandez, A.M., Gassman, N.R., Bae, S., Blashill, A.J., Tan, M.C (2017). Significant Engagement in Tanning Behaviors by Men at a U.S. University. Journal of Community Health. 1-4. DOI: https://doi.org/10.1007/s10900-0170464-y

FAO. (2001). Research and Extension: A Gender Perceptive. Women in Development Service (SDWW): Women and Population Division, Rome, Italy Government of Pakistan, 2008-09. Economic Survey of Pakistan, p: 177.Finance Division, Economic Advisors Wing, Islamabad, Pakistan.

Federal Republic of Nigeria (1999). Constitution of the Federal Republic of Nigeria. Abuja (1999).

Ihuoma, A.A., Okezie, N. O., Okonkwo, E. M. And Zubair, Y. (2001). "Current Status of the Nigerian Leather Industry, Part 2: Potential Hide and Skin Production” , Journal of the Society of Leather Technologists and Chemists, 85 (5): $170-182$.

Ismail R. (2005). Designing value Chain/Market for the poor (M4p) Programmes in Nigeria, Word Bank, 13th October, Sharaton towers Abuja, www.bdsknowledge.org/dyn

Iwala, O.S., (2006). Assessment of Youth in Agriculture Programme in Ondo State: Discernibility and Effectiveness in Onibi, G.E., Agele, S.O. Adekunle, V. A. J. and Akinbuluno, M.O. (Eds) 2006 proceedings of the $2^{\text {nd }}$ annual conference in Agricultural Research for development in Nigeria and agricultural technology. Federal University of Technology; Akure pp. $223-231$.

Nigerian Tanners Council (2009). List of Tanners and their Addresses, Tanners Council Registered in Nigeria, $31 / 32$ Niger Street, Kano. 
Ogunremi, O.O., Ogunremi, J.B. and Faleyimu, O.I (2012) Relevance and Benefits of Agricultural Youth Empowerment Programme to Participating Youth in Osun State, Nigeria. Asian Journal of Social Sciences \& Humanities. 1(2):33-38.

Olukosi, J.O. and Erhabor, P.O. (1988). Introduction to Farm Management Economics: principles and Applications. Agitab Publishers Ltd, Samaru-Zaria, Nigeria. 77-92.

Onuekwusi, G.C. and Effiong, E. O. (2002). "Youth Empowerment in Rural Areas through Participation in Rabbit Production; A Case of Akwa Ibom State, Nigeria.” Nigerian Journal of Rural Sociology, 4:95-99.

Shahzad, K.A.S. and Mahmud, S. (2006). Prevalence and determinants of asthma in adult male leather tannery workers in Karachi Pakistan: A cross sectional study. BioMed Central Public Health, 6: 292.

Umeh, G.N and Odo, B.I (2002): profitability of poultry production among school leavers in Anaocha Local Government Area of Anambra State Nigeria. Nigeria Journal of Animal Production 29: 76 - 80.

Umar, M., Ibrahim, M. A., Mustapha, B. M., Mohammed, I. B., Tashi, U. T., Obafemi, A. and Ahmad, G.I. (2017). Physicochemical Analysis and Microbiological Assessment of Tannery Effluent Discharged from Tanneries around Nigerias Kano Industrial Estates. Journal of Advances in Microbiology, 2(1): 1-12. DOI: 10.9734/JAMB/2016/31437. http://www.sciencedomain.org

Umar, S.M., Aminu, A. and Suhasini, K. (2015). Leather Value chain Study in Katsina State, Nigeria: Cost and Return Analysis. Research Journal of Agriculture and Forestry Sciences. 3(11): 10-20. ISSN 2320-6063

UNDP, (1995). Human Development Report. Oxford University Press, United Nations, New York

UNIDO (2004). United Nations Industrial Development Organization. Hides and Skins Improvement Expert Technical Report Prepared For The Government Of Nigeria. By The United Nations Industrial Development Organization. 1-46 PP 